WIDER Working Paper 2020/63

Resource sector concessions and spatial development in Southern Africa

Joan Halstein*

May 2020 
Abstract: This paper explores how Southern Africa can leverage its mineral resources to support growth and industrialization. It considers the aggregate and spatial effects of transport infrastructure improvements, and the relative benefits of financing these investments through resource sector concessions versus government expenditure. Using computable general equilibrium analysis, this paper simulates and compares the effects of (1) royalty rebates for infrastructure; (2) zero royalties for infrastructure; and (3) government revenue-financed infrastructure improvements in South Africa and the rest of Southern Africa. The findings suggest that infrastructure directly financed through government royalty revenue has stronger spatial and aggregate effects than concession-based investments. Nonetheless, concession-based investments are less distortionary and crowd-in private investments. Infrastructure improvements, regardless of the method of financing, stimulate activity in non-mining sectors, but sectoral changes are significantly different for South Africa and the rest of Southern Africa. The choice of financing depends on the objectives of the implementing government.

Key words: computable general equilibrium, infrastructure, resource sector

JEL classification: D58, F21, Q32, R53

\footnotetext{
* Independent researcher, Ottawa, Canada, jchalstein@gmail.com
}

This study has been prepared within the UNU-WIDER project Southern Africa - Towards Inclusive Economic Development (SA-TIED).

Copyright (C) UNU-WIDER 2020

Information and requests: publications@wider.unu.edu

ISSN 1798-7237 ISBN 978-92-9256-820-7

https://doi.org/10.35188/UNU-WIDER/2020/820-7

Typescript prepared by Gary Smith.

The United Nations University World Institute for Development Economics Research provides economic analysis and policy advice with the aim of promoting sustainable and equitable development. The Institute began operations in 1985 in Helsinki, Finland, as the first research and training centre of the United Nations University. Today it is a unique blend of think tank, research institute, and UN agency_providing a range of services from policy advice to governments as well as freely available original research.

The Institute is funded through income from an endowment fund with additional contributions to its work programme from Finland, Sweden, and the United Kingdom as well as earmarked contributions for specific projects from a variety of donors.

Katajanokanlaituri 6 B, 00160 Helsinki, Finland

The views expressed in this paper are those of the author(s), and do not necessarily reflect the views of the Institute or the United Nations University, nor the programme/project donors. 
Growth in the Southern African region has not exceeded 3 per cent per year since 2014. African Development Bank (AfDB 2019) estimates show that Southern Africa's growth fell from 1.2 to 0.7 per cent between 2018 and 2019, and is projected to grow by 2.2 per cent in 2020. With an average population growth rate of 1.8 per cent, this implies that incomes in the region will likely grow at less than 1 per cent. At these growth rates, the Southern African region will not be able to create the internal demand necessary for industrialization and structural change. A key challenge of the region is its natural resource dependence. While the region is endowed with vast mineral wealth, it has not been able to translate these assets into inclusive and industrialization-supporting growth. The literature suggests that part of the region's growth challenge derives from its poor infrastructure. It is well documented that critical infrastructure plays a catalytic role in stimulating regional growth and productivity. Notwithstanding, the Southern African region, like the rest of sub-Saharan Africa (SSA), faces a significant infrastructure gap. It is estimated that South Africa, for instance, will face an infrastructure gap of 53 per cent by 2040.

The present research explores how Southern Africa can leverage its vast mineral wealth to support industrialization and inclusive growth. It examines and compares the two approaches to financing infrastructure improvements. The first is based on the recent trend of resource-for-infrastructure (RFI) initiatives that are becoming increasingly popular in Africa, especially with Chinese investors. The second considers direct financing of infrastructure improvements using revenue from mineral royalties. Under the first option, governments offer investors concessions in exchange for investments in nonancillary infrastructure. The paper considers two types of resource sector concessions: one that rebates the revenue collected from mineral royalties, and another that waives mineral royalties in exchange for infrastructure investments. Our current understanding of the actual benefits of RFIs is limited by the lack of empirical studies on the subject. This issue has not particularly been addressed in the context of Southern Africa. This study aims to narrow the knowledge gap by quantifying and comparing the effects of concession-based and government-financed infrastructure improvements. It considers transport infrastructure because of its bottleneck-easing potential and catalytic impact on growth.

This paper addresses four questions: (1) How can Southern Africa leverage its mineral wealth to support its development goals? (2) Does the method of financing transport infrastructure improvements matter? (3) What are the spatial effects of different approaches to financing transport infrastructure improvements? (4) Does financing infrastructure improvements through resource sector concessions yield superior outcomes to the traditional government expenditure approach? To this end, I use static computable general equilibrium (CGE) analysis to simulate the effects of concession-based and government-financed transport infrastructure improvements in South Africa and the rest of Southern Africa. I separate South Africa from the rest of Southern Africa because it has a larger economy and a relatively different industrial base.

The findings of this research suggest that, yes, Southern African governments can harness their mineral resource wealth to support development initiatives through the efficient use of royalty revenue. Furthermore, while not as strong as the latter, concession-based infrastructure investments can yield positive sectoral and aggregate results. Concession-based schemes raise welfare in both regions. However, depending on the government's objectives, the method of infrastructure financing matters. If the objective is to achieve stronger spatial changes, then direct government investments yield superior results. If, instead, the objective is to stimulate spatial development in the least distortionary way, then concessionbased infrastructure arrangements are better.

The results also show interesting differences in spatial effects for South Africa and the rest of Southern Africa. For South Africa, transport infrastructure improvements result in an expansion of manufacturing 
output and exports. In contrast, the rest of Southern Africa experiences higher agriculture production and exports regardless of the method of financing. However, spatial and sectoral changes are stronger when infrastructure improvements are financed via direct government expenditure. Overall, some of the key findings of this research are consistent with earlier literature that transport infrastructure improvements stimulate economic activity and that revenue-financed infrastructure investments are more distorting. The literature, modelling framework, and results are discussed in the sections that follow.

The rest of the paper is organized as follows: Section 2 presents the background and reviews the existing literature on infrastructure and growth, and methods of financing infrastructure improvements. Section 3 outlines the analytical framework, including a discussion of key aspects of CGE modelling and the structure of the Global Trade Analysis Project (GTAP) model. The data, calibration process, structure of shocks, and simulation design are discussed in Section 4. Section 5 concludes the paper and offers suggestions for future research.

Background and literature review

\subsection{Background}

The Southern African region is endowed with vast mineral wealth. It produces 35 per cent of the world's diamonds, with five Southern African countries ranking among the top 10 global diamond producers. South Africa ranks ninth in gold production and has the world's second largest gold reserves after Australia. Furthermore, South Africa has 90 per cent of the world's platinum reserves and supplies 74 percent of global demand. Namibia and Zambia rank among the top producers of uranium and copper, respectively. Furthermore, the region has substantial unexplored resources, as exemplified by the recent and continued discovery of mineral deposits in previously unexplored areas; uranium and gold in Zambia, for instance, and diamonds and platinum in Zimbabwe. The region is also an important destination for foreign direct investment (FDI). The region continues to attract significant FDI even amid declining global flows. According to UNCTAD (2019), FDI flows to Southern Africa averaged US $\$ 4.2$ billion in 2018. South Africa remains Africa's second most important FDI destination after Egypt.

Despite its vast wealth and FDI flows, the region has failed to translate these assets into inclusive and industrialization-supporting growth. The region remains undiversified and growth is too low to create the necessary internal demand for industrialization. According to the AfDB, GDP growth in Southern Africa has remained below 3 per cent since the 2014/15 precipitous fall in commodity prices. In the past five years, country-specific growth rates have either been negative or close to zero.

Overall, the AfDB projects that the region will grow by 2.2 and 2.8 per cent in 2019 and 2020, respectively. With an average population growth rate of 1.8 per cent, this implies that aggregate income is projected to grow at less than 1 per cent. Given its current trajectory, the Southern African region is likely to fall further down the development ladder. Furthermore, because the region is resourcedependent, countries in the region remain vulnerable and prospects for growth bleak if discoveries of new mineral deposits in other parts of the world and the development of mineral substitutes continue to evolve. $^{1}$

The region has the unique challenge of being resource-dependent. It is well documented that resource dependence can have consequential negative growth effects. Quoting Sachs and Warner (1997), Venables (2016) points out that after controlling for initial per-capita income, investment in physical and human capital, and institutional factors, a 10-percentage point increase in the resources-to-exports ratio

\footnotetext{
${ }^{1}$ The IMF defines resource dependency as deriving at least 20 per cent of export revenue from non-renewable resources.
} 
can reduce annual growth by up to 1.1 percentage points. Furthermore, the presence of a large resource sector can crowd-out the productive activities of other sectors, a phenomenon known as the 'Dutch Disease'. There are a few exceptions: resource-rich nations such as Malaysia and Chile have managed to develop vibrant industrial sectors through carefully crafted and managed policies. The challenge for Southern Africa is its lack of diversification, which leaves the economies susceptible to external shocks. Venables (2016) argues that structural change resulting from a large resource sector is not necessarily a problem. He explains that the problem arises when such changes interact with pre-existing market failures.

Market failures are quite significant in Southern Africa. Supply-side bottlenecks reinforce market failures by limiting the adjustment of factor markets to positive economic stimuli. These bottlenecks include inefficient or absent growth-catalysing infrastructure, especially in the transportation and electricity sectors. According to Saghir (2017), poor infrastructure reduces growth by 2 per cent and productivity by 40 per cent annually. Part of the region's growth and industrialization problem lies in the state of its infrastructure. The World Bank finds that attaining a level of infrastructure development comparable to Mauritius, Africa's poster child for infrastructure development, can potentially raise per-capita GDP growth by 2.2 per cent. The region, like the rest of Africa, faces a sizeable infrastructure gap. South Africa, in particular, faces a projected 53 per cent gap by 2040 (Metcalfe and Valeri 2019).

The reason most of the FDI in Southern Africa has failed to garner sustained growth is because it flows to extractive industries. Unlike non-resource sector FDI, which has potential growth effects on productivity and knowledge spillovers, resource sector FDI tends to limit the growth of local communities by creating economic enclaves. It fails to stimulate the development of backward and forward linkages, inevitably contributing little to the development of local economies. Bunte et al. (2017) contend that if properly managed and coordinated through deliberate government policy, resource sector FDI can result in growth benefits for local economies. Importantly, 'there are few areas of economic policy-making in which the returns to good decisions are so high -- and the punishment of bad decisions so cruel - as in the management of natural resource wealth' (Strauss-Kahn 2010).

Studies suggest that traditional sources of infrastructure financing, such as public revenue and official development assistance (ODA), are insufficient to close this gap. First, countries in the region have limited capacity to finance public infrastructure projects. In 2019, the average tax revenue to GDP ratio was 18.9 per cent. While this figure masks regional disparities, revenue collections in the region are long compared to the OECD average of 35-40 per cent. Second, flows of ODA, the second most important source of infrastructure funding, target specific infrastructure projects such as health and education, and have declined significantly. In 2016, ODA to Africa fell by 1.6 per cent. Furthermore, countries in Southern Africa are not part of the top 10 aid recipients in Africa. This leaves the third source of infrastructure funding: FDI.

A growing body of literature acknowledges that the private sector has to play a key role in bridging this infrastructure gap. Venables (2016: 162) explains that ultimately 'it is the private sector that will create the sustainable jobs and economic growth, so resource management has to be done in a manner that will support private sector investments'. The role of the private sector has to be carefully managed or coordinated, however, if it is to benefit the region. Also, the literature suggests that resource extraction can be leveraged to provide domestic assets that can support inclusive growth and sustainable growth (Bunte et al. 2017; Collier 2014; Toledano 2012). This approach, RFI or infrastructure-tied resource concessions, is gaining prominence among African governments. Under the RFI model, either offer mining rights or ores in exchange for concessional/non-concessional loans targeted at infrastructure projects or offer investors mining rights with the condition that they provide non-ancillary infrastructure.

The latter is a barter-like system that has several advantages, especially in cases in which the ability of host governments to tax resource rents is limited by institutional constraints. In most cases, govern- 
ments have less information relative to resource companies. The barter-like system overcomes weak government capacity to finance much-needed infrastructure projects. Furthermore, requiring investors to provide infrastructure instead of charging mineral royalties can eliminate the time inconsistency problem of resource sector agreements, and reduce the reputation risk that can deter new investments. Also, resource sector investors have little incentive to provide infrastructure other than that which supports their production objectives. RFI is a practical way of ensuring that host-country communities benefit from natural resources (Halland et al. 2014). Finally, it creates a sense of giving back to the community. Notwithstanding, scholars have voiced concerns that these types of infrastructure deals disadvantage the FDI recipients and have advocated for the need for in-depth analysis of such infrastructure arrangements.

Chinese investment in Africa typifies the RFI model. While China is a more recent source of FDI, its influence in Southern Africa is broad and growing. Angola, South Africa, Zambia, and Zimbabwe all enjoy significant Chinese FDI relative to total FDI, and the bulk of this FDI is in the resource sector. Chen et al. (2018) compiled a list of projects in the top 10 African countries receiving Chinese FDI, and five of these countries are in Southern Africa. Liberia, Congo DRC, and Ghana are examples of countries with RFI arrangements in other parts of Africa. Liberia, for instance, has had an infrastructuretied resource investment policy since 2006. According to Parks (2017), Liberia has a targeted strategy aimed at maximizing the multiplier effects of such infrastructure projects. A recent study by Bunte et al. (2017) found that mining concessions, in particular Chinese mining concessions, have positive growth effects on local economies. For the Southern Africa region, the potential benefits of RFI are yet to be analysed.

\section{$2.2 \quad$ Literature}

\section{Infrastructure and growth}

Inadequate, poor, and unreliable infrastructure increases supply-side and demand-side transaction costs. As a consequence, it hinders the creation of internal markets and the demand required to create a dynamic industrial base and its associated growth. The relationship between infrastructure and growth has received considerable attention in the literature. It is well documented that critical infrastructure plays a catalytic role in stimulating regional growth and productivity, as it promotes growth through its effects on the productivity of existing firms, skills transfer, and the crowding-in of private investment (Straub 2008; Straub and Terada-Hagiwara 2011). Effects of infrastructure investment go beyond direct effects on productivity, as infrastructure tends to have both multiplier and large spillover effects. Straub (2008) identifies potential channels through which multiplier effects occur: (1) the reduction of adjustment costs; (2) enhanced labour productivity through the reduction of commute times, and improved organization, communication, and the flow of ideas. In the case of transport infrastructure, the resulting reduction in transportation costs can stimulate the development of economies of scale, enhanced competition, more efficient flow of information, and better inventory management.

However, the results of empirical studies are varied because they are often constrained by methodological and data issues. Rovolis and Spense (2002), reviewing 13 studies on public capital, find that public capital enhances productivity and crowds-in investment. Fernandez and Montuenga-Gomez (2003) examine the effects of public infrastructure on the Spanish economy. They find that while sectoral effects differ, the provision of public infrastructure has strong aggregate growth effects. Studies also find spatial variations in the effects of transportation projects. In some cases, the building of an efficient road network can increase unemployment, while in most cases it raises both productivity and the stock of private capital (Ayogu 2007). 
What drives economic activity is the accessibility of spatially dispersed markets. Robson et al. (2018) explain that the role of transport in the economy is to allow for the interaction of spatially separated entities for a cost. By lowering transportation costs, good transport infrastructure can potentially ease the flow of factors of production and goods and foster a more balanced regional distribution of economic activity. For resource-dependent countries, this can consequently offset the Dutch Disease by stimulating activity in tradable sectors. Venables (2016) highlights the importance of supply-side responses in offsetting the Dutch Disease. Theoretically, in the absence of bottlenecks, the presence of an untapped labour supply can result in growth when the resource sector booms because previously unemployed labour is absorbed into a booming resource market. The absence of bottlenecks such as poor transport infrastructure can in part explain why some countries like Malaysia and Botswana have managed to translate mining wealth into economic development. Furthermore, transport infrastructure has large spillover effects, so improving transportation can result in the development of other types of infrastructure.

Transport infrastructure influences the spatial distribution of economic activity and aggregate growth. Additionally, it can have strong growth effects; however, higher growth can worsen inequality. Straub (2008) explains that transport infrastructure policies that facilitate transport between regions can spur growth while increasing inequality. Conversely, policies that improve infrastructure within poor regions can reduce inequality but are likely to stifle growth. Notwithstanding, the aggregate growth effects can, in the long run, reduce inequality.

\section{Financing infrastructure improvements: infrastructure-tied resources concessions}

Straub (2008) explains that the way infrastructure projects are financed is not neutral and can potentially crowd-out private investment. For instance, infrastructure projects financed through taxation or domestic borrowing can invariably crowd-out public investments. In the presence of an inefficient tax system and already high domestic borrowing, these sources of finance can result in perverse outcomes for developing countries.

Furthermore, most governments in the Southern African region have revenue deficits, while investors in extractive sectors have little incentive to invest in non-ancillary infrastructure. A growing body of literature suggests the use of resource concessions to secure development-catalysing infrastructure can be less distortionary. In the presence of information asymmetries, this is one way to ensure that investors are giving back to the local economy. In most cases, policy makers have less information about the geological and commercial potential of resource-oriented projects than investors (Boadway and Keen 2010). If properly managed, extractive resources can make a meaningful contribution to the development of resource-rich countries/regions. Parks (2017) asserts that while resource sectors are often associated with low growth, no growth, or negative growth outcomes, policy choices matter.

A series of articles (Bunte et al. 2017; Halland et al. 2014; Parks 2017; Toledano 2012) consider RFI concessions/agreements. Under RFI arrangements a host government grants resource extraction rights to an investor contingent on the investor developing non-ancillary infrastructure. Infrastructuretied resource concessions constitute a commitment mechanism enabling host governments to ensure that providers of FDI devote part of this FDI to providing non-ancillary infrastructure-infrastructure that is conducive to development. As a concession, governments can offer to reduce royalty rates. Reducing or removing royalty requirements reduces the distortionary effects of mining taxes by reducing (a) disincentives created by taxation, and (b) time inconsistency issues associated with mining taxation.

Under such an arrangement, targeted infrastructure investments can crowd-in other types of investments, stimulate firm activity, develop local value chains, and reduce unemployment (Bunte et al. 2017). Lin 
and Wang (2014: 76) claim that RFI connects "resource extraction with "bottleneck-releasing" infrastructure to otherwise segregated supply chains, thereby reducing transaction costs'. They explain that this type of infrastructure provision overcomes foreign exchange constraints that limit infrastructure provision. Also, if well designed and monitored, such programmes can result in development outcomes such as roads, schools, and jobs within a short period of time.

The speed of infrastructure delivery under the RFI model is also highlighted by Collier (2014) and Halland et al. (2014). Collier finds that infrastructure delivery tends to be faster under resource-tied arrangements. Similarly, Halland et al. explain that benefits to the host country and its citizens can be substantial and years ahead of what would have been possible under an alternative model. Venables (2016: 176) adds that infrastructure investment concessions/agreements are 'a commitment to transform subsoil assets into surface assets, rather than into current consumption and to do so in a relatively rapid manner'. Another advantage of this barter-like arrangement is that it overcomes weak government capacity to finance key infrastructure projects.

From a political economy perspective, Boadway and Keen(2010) maintain that RFIs can, potentially, minimize time inconsistency issues by providing legal assurance that governments will not raise future royalty rates provided the projects are completed and maintained by investors. Also, as is often the case in countries with weak governance, corruption prevents revenue from resource sectors being used to support local development initiatives. A barter-like system would ensure that key infrastructure is built. Halland et al. (2014: 6) posit that RFI is attractive because 'public infrastructure constructed early in the extractive project cycle may provide legitimacy for a democratically elected government or a nondemocratic one with the perceived need for some form of legitimacy'.

The RFI model is becoming increasingly popular in resource-rich countries. In Africa, China is the largest source of RFI. Chinese infrastructure projects include roads, power dams, telecommunications, and recreational structures. Empirical studies suggest that positive benefits have been realized in Chile, Liberia, and other countries. Liberia, for instance, has carefully managed FDI as a centrepiece of its development strategy. According to Bunte et al. (2017), Liberian authorities have pursued an investment strategy requiring investors to provide public goods in specified geographic areas. Additionally, they offer resource sector concessions on the condition that investors hire local labour, support domestic value chains, and assist local communities through social responsibility activities. Bunte et al.'s (2017) analysis of the economic effects of RFI in Liberia yield three key results. First, RSI has had positive growth effects. Second, comparing FDI in the agriculture and resource sectors, they find resource sector FDI to yield positive growth effects. Finally, they find that, relative to the USA, Chinese investment in Liberia has positive and stronger growth effects.

\subsection{Objectives and research questions}

The overarching objective of this research is to examine how governments in Southern Africa can leverage their mineral resources to support their industrialization and development goals. The secondary objectives are threefold: first, to contribute to the broader understanding of new approaches to closing the infrastructure gap by quantifying the effects of infrastructure-tied resource concessions. Second, to examine and compare the relative benefits of concession-financed infrastructure investments vis-à-vis traditional government-financed projects. And finally, to offer insights on how spatial development is impacted by various approaches to infrastructure financing. To this end, this work seeks to answer the following questions:

- How can Southern Africa leverage its mineral wealth to support its development goals?

- Does the method of financing transport infrastructure improvements matter?

- What are the spatial effects of different approaches to financing transport infrastructure improvements? 
- Does financing infrastructure improvements through resource sector concessions yield superior outcomes to the traditional government expenditure approach?

\subsection{Contribution and significance}

This work contributes to the discussion on strategies for promoting spatial development and industrialization in Southern Africa. Furthermore, it contributes to the evolving body of literature examining the economic effects of resource-tied infrastructure investments (Bunte et al. 2017; Collier 2014; Toledano 2012). To my knowledge, no empirical analysis has been undertaken to explore the economic effects of resource-tied infrastructure investments in Southern Africa. Recently, empirical studies have considered the effects of such investments in Liberia. Furthermore, the analysis of these types of investments within the context of CGE analysis is yet to be done.

The significance of this work is threefold. First, Southern Africa's continued poor growth performance and the region's vulnerability to external shocks highlight the importance of examining strategies for economic diversification and growth. Second, the region faces a sizeable infrastructure gap and revenue constraints; an examination of new and non-traditional methods of financing infrastructure projects therefore is timely and relevant. Finally, five of Southern Africa's countries are among the top 10 recipients of Chinese FDI in Africa. The bulk of Chinese FDI in Africa is to the resource sector, and it also is being increasingly combined with infrastructure projects. Scholars have voiced concerns that these types of infrastructure deals disadvantage the FDI recipients and have advocated for the need for in-depth analysis of such infrastructure arrangements.

\section{3}

Analytical framework

To address the research questions, I use a four-region, five-sector static CGE model with five factors of production. Several approaches in the literature are used to model the economic effects of transport infrastructure investments, including benefit-cost analysis (BCA), econometric modelling, and land use and transport infrastructure (LUTI) models. While all three approaches offer valuable insights, they fail to capture the economy-wide effects of transport improvement shocks. Because the premise of this paper is to examine how the various approaches to transport infrastructure investment affect spatial development, the standard approach is to use a model that captures feedback effects. CGE analysis captures the wider economic impacts of infrastructure shocks and allows for the simultaneous analysis of several complex factors. Importantly, it also incorporates sectoral and regional linkages.

CGE models treat the economy as a whole, and a shock in one part of the economy affects all other parts. Demand and supply schedules in various markets are functions of prices of other markets, and as a consequence, a fall in transport costs has implications for all other markets. The theory underlying CGE models is that consumers and producers act as optimizing agents who respond to changes in relative prices by modifying their market decisions. When an economy experiences an economic shock, agents in all markets adjust their behaviour, which affects other markets until the economy reaches a new equilibrium. Conventional spatial-growth models ignore these feedback effects. Notwithstanding, CGE models lack spatial details that standard approaches like CBA incorporate. I examine spatial effects by looking at changes in employment, land rates, sectoral private capital, and output.

\section{Capturing spatial implications}

Spatial bottlenecks influence the location of economic activity. The model used in this analysis explores the spatial effects of easing transport bottlenecks by examining changes in employment, sectoral output, 
land rates, and private capital. Changes in these sectoral variables will also reflect the bottleneck-easing potential of transport infrastructure improvements.

\section{Modelling royalties and resource concessions}

A royalty is defined as a charge levied on the extraction of the resource itself. These are charges for the right to take ownership of the resource and essentially are payments that governments receive from investors for the use of the resource. In mining, the resource is mineral-rich land, and it is for this reason that I model mineral royalties as land-use taxes in the mining sector. A concession can take the form of a lower royalty rate or a subsidy, in exchange for infrastructure investment. In the model, I consider two types of mining sector concessions: the outright removal of mineral royalties and the provision of rebates/subsidies to royalty-paying mining firms.

\section{Modelling improvements in transport infrastructure}

On the production side, there are three main approaches to modelling transportation improvements: capital shock, productivity shock, and margin shock. A capital shock alters the quantity of capital and raises the quantity of production and output. Capital improvements can be modelled as public capital or as intermediate inputs. An increase in infrastructure capital lowers the cost of related intermediate inputs such as transport and communications that enter the firm's production function. A productivity shock improves the productivity of factors of production. Finally, margin shocks represent improvements in transport infrastructure via the reduction in transport costs. Transport margins measured as the CIF/FOB ratio can be as high as 40 per cent in land-locked countries like Zambia and Botswana. ${ }^{2}$

Poor transport infrastructure is reflected in high trade costs. Trade costs represent the cost of doing business including transaction, tariff, transport, and time costs. In most cases, the bulk of the cost of a good or commodity derives from trade costs. Limão and Venables (2001) find that in African countries, intra-African trade costs 136 per cent more and trade volumes are 6 per cent lower than predicted. Furthermore, 59 per cent of these transportation costs are due to poor infrastructure. In modelling transport infrastructure improvements, I consider how infrastructure investments impact consumer prices via their effects on trade costs. This study uses the iceberg method to model improvements in infrastructure. All agents receive an import-augmenting technical shock analogous to the reduction in transport margins and increase in productivity.

\subsection{The model}

The standard GTAP model is used in this analysis. The model consists of five main parts: production and supply; consumption and final demand; international trade; market clearance; and the model closure. Here, I briefly discuss the key features of each of these parts.

\section{Production}

Output is determined by the factors of production, input prices, and technology. Within each of the five sectors, firms minimize the costs of producing a given quantity of output and allocate output between domestic and foreign markets so as to maximize profits. Changes in relative prices will therefore affect the way output is produced, and how they export and sell in domestic markets. This subsection briefly discusses the main elements of the supply side of the model.

\footnotetext{
${ }^{2}$ CIF and FOB are terms used in the international shipment of goods. CIF refers to cost insurance freight, while FOB means free on board.
} 
Production exhibits constant returns to scale (CRTS) and firms in all sectors at competitive-equilibrium prices are market determined. While exhaustible, I assume that mining resources operate under CRTS, at least within the referenced period. Production is modelled using the three-stage (nested) production process depicted in Figure 1. At each stage, firms optimize by selecting a combination of inputs that minimize production costs.

Figure 1: Production technology

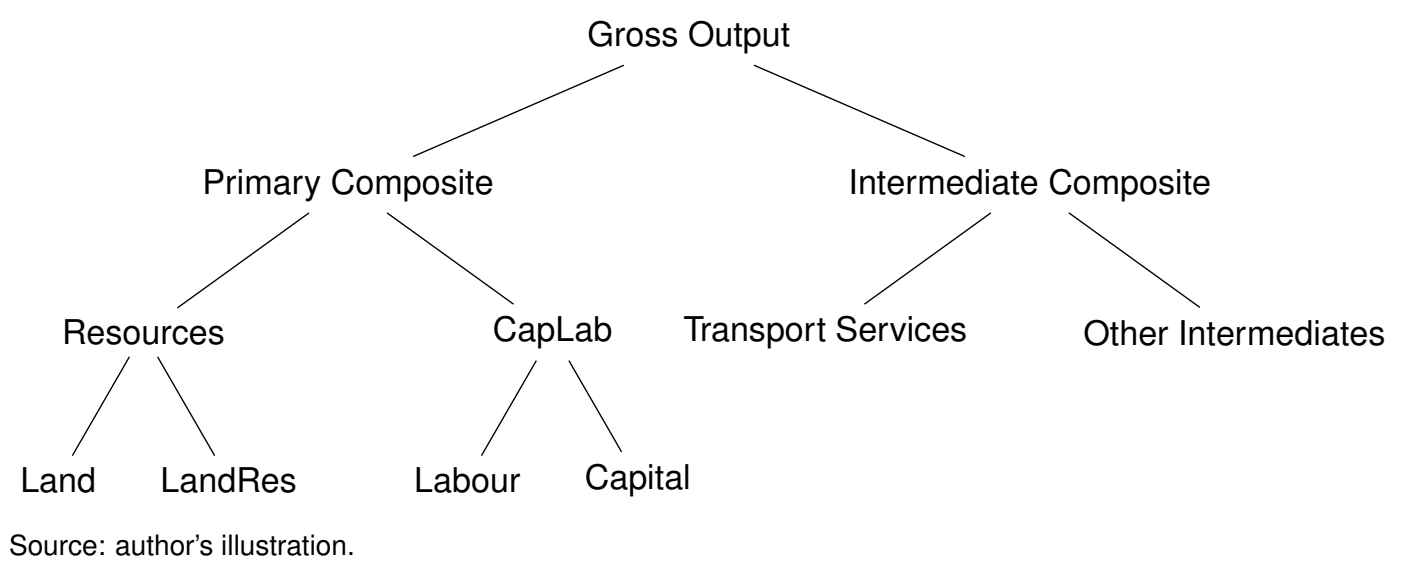

The nested production structure shown in Figure 1 is important because it allows for the modelling of different substitution possibilities among classes of inputs. The top-level nest shows that a firm produces gross output by combining composite primary and intermediate inputs. These two classes of inputs can be complementary, but within the intermediate input category (level II) firms can substitute between various intermediate inputs.

Assumptions on the substitution between classes have important implications for the model simulations. For instance, transport services are separated from the rest of the intermediate inputs if modelled as complementary to other intermediate inputs, and improvement in transport services will increase the demand for other intermediate inputs. If the two are substitutes, then an improvement in transport services will result in a fall in demand for other intermediate inputs.

Once output is produced, firms decide how to allocate output between domestic and international markets to maximize profits. This allocation is described by the constant elasticity of transformation structure described by Equation 2. This structure treats domestic and exported goods as imperfect substitutes. When domestic prices fall, optimizing firms will allocate more output to the export market and vice versa. This formulation is particularly important in explaining the dynamics that follow transport infrastructure shocks when transport improvements are modelled using the iceberg approach. The iceberg analogy from improvements in transport infrastructure is based on the premise that a fraction of traded goods melt in transit. Therefore, if infrastructure improves, the fraction of goods lost in transit will be reduced.

\section{Final demand}

In this model, final demand comes from a representative regional household. The regional household allocates expenditure between private consumption, government consumption, and savings. Preferences underlying final demand are given by a nested Cobb-Douglas (C-D) utility function. Under this formulation, budget shares for each of the components making up final demand are assumed to be fixed. This means that whenever there is a shock, the share of expenditure on private consumption, savings, and government consumption will not change:

$$
U_{r}=U_{h r}^{\alpha} U_{g r}^{\beta} S_{r}^{1-(\alpha+\beta)}
$$


where $r$ denotes the region, $U$ per-capita utility, $U_{h}$ private household utility, $U_{g}$ government utility, and $S$ savings. $\alpha$ and $\beta$ are distributional parameters.

The regional household receives income from the sale of endowments and tax revenue. It engages in optimizing behaviour by allocating expenditure between private consumption, government consumption, and savings. The nesting structure allows for the modelling of different assumptions of the regional household. For instance, the second nest defines the preferences that govern private consumption, savings, and government consumption separately. The nesting structure shows how these three components influence regional consumption. Changes in transport infrastructure will affect final demand as the flow of goods and services becomes more efficient. Also, the nature of financing infrastructure improvements affects government consumption, which affects regional utility and, consequently, welfare.

\section{Private household consumption}

The private household optimizes by allocating income between domestically produced and imported goods. It selects a combination of goods that yields the greatest satisfaction given prevailing prices and income. This means that an optimizing consumer will adjust its consumption of domestic and imported goods depending on the relative prices of those goods. The demand system underlying these preferences is given by the constant difference elasticity (CDE) functional form. Under this formulation the private household's utility function is non-homothetic. This means that as incomes change, consumers can purchase proportionately more luxury goods. Shocks that result in higher income can lead to the expansion of domestic luxury/durable goods manufacturing or imports as demand increases.

\section{Government consumption}

Government consumption is an important source of final demand. In each region, the government finances consumption expenditure through taxes. In the model, I define four types of taxes: the consumption tax (value-added tax), direct taxes (taxes on factors of production including mining land), indirect taxes, and tariffs. Government revenue is defined as:

$$
G_{Y}=T_{\text {cons }}+T_{\text {Direct }}+T_{\text {indirect }}+T_{\text {imp }}
$$

Government spends this income on transfers and government consumption. The latter includes public investment.

\section{International trade and transport}

The regions/countries in the model are connected via international trade flows. We assume that products are differentiated on the basis of region. To this effect, diamonds produced in South Africa are substitutes for diamonds produced in Botswana. This is based on the Armington assumption that assumes that commodities, while identical in all respects, can be differentiated on the basis of their region of origin. The Armington assumption that allows for two-way trade in similar goods is seen in the empirical literature. Furthermore, it prevents the extreme patterns of specialization observed in standard/theoretical models of international trade. Data on the region's international trade suggest that the whole Southern Africa region is resource dependent. According to the IMF definition, the region is resource rich because exports account for more than 20 per cent of export revenue.

\section{Transport margins}

Transport costs are captured in the trade margins defined in Equation 3. Equation 3 embodies the iceberg costs in that a constant fraction of goods $m_{r s}$ melts away in transit. The total transport cost is the cost of 
producing these goods that 'melt' in transit:

$$
m_{i r s}=\left(\frac{T_{i r s}^{-} 1}{T_{i r s}}\right)
$$

Because of this, per-unit transport costs are a destination-specific percentage of the commodity's producer price in region $r\left(P_{i r s}^{t}\right.$ rans $=\left(\tau_{i r s}-1\right) P_{i r}$ (Bosker and Buringh 2018). In GTAP, iceberg transport costs are modelled using the following equation:

$$
\begin{aligned}
q x s_{i r s} & =-a m s_{i r s}+q i m_{i s}-\sigma_{m}^{i}\left[p m s_{i r s}-a m s_{i r s}-p i m_{i s}\right] \\
\operatorname{pim}_{i s} & =\sum_{k} \theta_{i k s}\left[p m s_{i k s}-a m s_{i k s}\right]
\end{aligned}
$$

where $\sigma_{m}^{i}$ is the elasticity of substitution among imports; $q x s_{i r s}$ is the percentage change in bilateral exports of $i$ from one region to another; pmsirs is the percentage change in the price of imports; pim $_{i s}$ is the percentage change in the average price of imports; and ams $s_{i r s}$ is the percentage change in the price of $i$ traded between regions due to unobserved trade costs, including weak infrastructure.

\section{Market clearance and model closure}

General equilibrium is a set of prices that clears all the markets. To achieve general equilibrium, the following conditions must hold. First, all firms have zero profits. The zero-profit condition implies that, in equilibrium, the value of a firm's output must equal the sum of its expenditure on intermediate and primary inputs such that economic profits are zero. Second, the incomes balance ensures that the regional households satisfy their budget constraint; income equals expenditure. Third, the market clearance condition ensures that supply and demand schedules in the factors and goods markets are equal.

The model closure consists of rules that govern micro- and macro-variables to ensure that the number of endogenous variables equals a number of equations in the model. The micro-closure conditions refer to clearing factors markets. The model assumes that labour supply and demand quantities are equal. Similarly, quantities demanded of capital, land, and resources are equal to ensure factor market balances. Because we assume that land and resources are fixed, prices of these factors adjust to maintain market balances.

Macro-closure involves specifying rules regarding the government balance, the savings-investment balance, and the trade balance (current account). The choice of closure is determined by the model objectives and the key features of the regions under consideration. In this model, tax policy instruments are fixed and the real fiscal balance adjusts to changes in revenue receipts. The model is savings-driven; gross regional investment adjusts to savings through the expected rate of return. Finally, because movements in the real exchange rate are important in resource-rich economies, the model holds the overall trade balance constant; the real exchange rate adjusts to maintain the current account balance. The world price of factors of production is the model's numeraire price.

\subsection{Data, aggregation, and calibration}

The underlying database is the GTAP Africa Vol. 2a, which captures the world economy in 2007. Africa Vol. 2a is based on GTAP Vol. 8 (Narayanan et al. 2012), and consists of 42 regions, 32 of which are African countries/regions and 10 of which are aggregated regions representing the rest of the world. It has 57 sectors and five primary inputs.

For the objectives of this study, I aggregate the database into four regions: South Africa (RSA), the rest of Southern Africa (RSNA), the rest of sub-Saharan Africa (SSA), and the rest of the world (ROW). The original 57 sectors are aggregated into five: Agric, representing agriculture and extractive activities other 
than mining; Mining (mining); Mnfc (manufacturing); Trans (transportation); and Osvcs, representing all other services. The model preserves the factor aggregation from the underlying database. Primary factors include skilled and unskilled labour, physical capital, resources, and land. The aggregation scheme is illustrated in Table 1.

\begin{tabular}{ll} 
Table 1: Aggregated regions, sectors, and primary factors \\
\hline Regions (4) & South Africa \\
RSA & Rest of Southern Africa \\
RSNA & Rest of sub-Saharan Africa \\
SSA & Rest of the world \\
ROW & \\
\hline Sectors (5) & Agriculture \\
Agric & Mining \\
Mining & Manufacturing \\
Mnfc & Transportation \\
Trans & All other services \\
Osvcs & \\
\hline Primary factors (5) & Land \\
Land & Unskilled labour \\
UnSklab & Skilled labour \\
Sklab & Physical capital \\
Capital & Natural resources \\
NatRes &
\end{tabular}

Source: author's construction based on GTAP Africa database Vol. 2a.

Parameters drive the results of the model. In this study, regional and intersectoral linkages are important. Parameters explaining these linkages derive from the GTAP database and the literature. Technical, shift, and share parameters are calibrated to replicate the baseline equilibrium.

\subsection{Description of shocks and simulations}

\section{Experiment 1 (Sim 1)}

The first experiment (Sim 1) involves the application of revenue-neutral mineral royalties rates and a 10 per cent transport infrastructure improvement shock in RSA and RSNA. This scenario represents the case in which the government returns the royalty revenue to mining companies in exchange for transport infrastructure investments.

Experiment 2 (Sim 2)

The second experiment (Sim 2) involves zero royalties combined with a 10 per cent transport infrastructure shock. This represents the concessionary case in which the government waives royalties in exchange for transport infrastructure.

Experiment 3 (Sim 3)

The third experiment ( $\operatorname{Sim} 3$ ) involves non-revenue-neutral mineral royalties and a 10 per cent infrastructure shock. This represents the case in which revenue collected from royalties is used by the government to directly finance infrastructure shocks. The three experiments are summarized in Table 2. 


\begin{tabular}{lcccc}
\hline & Royalties & $\begin{array}{c}\text { Revenue } \\
\text { neutrality }\end{array}$ & $\begin{array}{c}\text { Infrastructure } \\
\text { shock }\end{array}$ & $\begin{array}{c}\text { Source of } \\
\text { investment }\end{array}$ \\
\hline Base equilibrium & Zero & NA & Zero & NA \\
Counterfactual 1 (Sim 1) & Positive & Yes & 10 per cent & Private sector \\
Counterfactual 2 (Sim 2) & Zero & Yes & 10 per cent & Private sector \\
Counterfactual 3 (Sim 3) & Positive & No & 10 per cent & Government \\
\hline
\end{tabular}

Source: author's construction.

\section{$4 \quad$ Results and discussion}

The basic premise of this paper is to quantify the effects of combining resource sector concessions with infrastructure investment on spatial development in Southern Africa. The results are driven by the elasticities and parameters used in the GTAP database and obtained from the literature. For computational simplicity, I simulate the effects of policy shocks in one period. An import-augmenting technical change shock will lower the effective price of imports (a reduction in trading costs). From Equations 4 and 5, we see that this occurs through different avenues.

First, a positive infrastructure shock resulting in fewer transport bottlenecks will lower the effective price of imports from exporter $r$ to region $s$; this will induce substitution from other exporters to region $r$. The second avenue has an opposite effect. Because the effective quantity of the good increases, less is needed to meet the demand of the importer. Third, the lower effective price of imports will result in an increase in import demand at the expense of domestic purchases. The net effect therefore depends on the relative elasticities of these three effects.

We would expect that a reduction in trading costs in South Africa would increase the demand for South African imports and the share of imports from South Africa by other regions. In the presence of concessionary tax breaks in the mining sector, we would expect a rise in imports from South Africa and a stimulation of output in other sectors, and also associated positive employment and welfare effects. Tables 3-6 summarize the results of the simulations. Three policy scenarios are compared: (1) a nonconcessionary case, in which the government invests in infrastructure in the presence of mining royalty revenue; (2) the case in which revenues generated from mining royalties are neutral and infrastructure shock derives from mining; and (3) the case in which mining concessions are applied in combination with positive infrastructure shocks (the case of concessionary infrastructure shocks).

\subsection{Aggregate effects}

The effects of financing transport infrastructure improvements via RFIs and direct government expenditures using royalty revenues are presented and compared in Table 3. Output effects are measured as changes in GDP relative to the baseline equilibrium. Changes in welfare are given by the equivalent variation (EV) as a percentage of initial income. The standard definition of EV is that it is the increase in income that would be required to maintain the well-being of citizens at the pre-policy level. In GTAP, the EV measure is comprehensive, capturing both changes in factor incomes and utility.

Table 3: A comparison of aggregate effects

\begin{tabular}{|c|c|c|c|c|c|c|c|c|}
\hline & \multicolumn{2}{|c|}{ RSA } & \multicolumn{2}{|c|}{ RSNA } & \multicolumn{2}{|c|}{ SSA } & \multicolumn{2}{|c|}{ ROW } \\
\hline & $\begin{array}{c}\text { GDP } \\
\text { change } \\
(\%)\end{array}$ & $\begin{array}{c}\text { Welfare } \\
\text { EV/Y } \\
(\%)\end{array}$ & $\begin{array}{c}\text { GDP } \\
\text { change } \\
(\%)\end{array}$ & $\begin{array}{c}\text { Welfare } \\
\text { EV/Y } \\
(\%)\end{array}$ & $\begin{array}{c}\text { GDP } \\
\text { change } \\
(\%)\end{array}$ & $\begin{array}{c}\text { Welfare } \\
\text { EV/Y } \\
(\%)\end{array}$ & $\begin{array}{c}\text { GDP } \\
\text { change } \\
(\%)\end{array}$ & $\begin{array}{c}\text { Welfare } \\
\text { EV/Y } \\
(\%)\end{array}$ \\
\hline Sim 1 & -2.5 & 4.9 & 0.03 & 2.9 & -0.35 & 0.2 & -0.02 & 0.8 \\
\hline $\operatorname{Sim} 2$ & -2.2 & 5.2 & 1.16 & 3.7 & -0.25 & 0.2 & -0.01 & 0.7 \\
\hline Sim 3 & -4.7 & -48.2 & 6.31 & 22.8 & 4.13 & 31.7 & -0.09 & -1.7 \\
\hline
\end{tabular}

Source: author's construction based on simulation results. 
According to Table 3, aggregate effects vary considerably in the two policy-implementing regions. South Africa experiences a fall in GDP relative to the baseline equilibrium under all three policy scenarios. GDP falls by 2.5 and 2.2 per cent when transport infrastructure improvements are financed through resource sector concessions, while GDP falls by 4.7 per cent when these improvements are financed directly through government royalty revenues. In contrast, the rest of Southern Africa (RSNA) experiences higher GDP relative to the baseline regardless of the source of infrastructure financing.

While the change in GDP under the rebate case is positive, it is negligible. The zero-royalty for infrastructure case increases RSNA's GDP by 1.2 per cent. Importantly, government-financed infrastructure improvements have stronger output effects ( 6.3 per cent). For both regions, concession-based infrastructure improvements yield welfare gains. Interestingly, there is a significant difference in welfare effects between South Africa and the rest of Southern Africa when the government uses royalty revenues to finance infrastructure improvements. South Africa's EV-to-income ratio falls by 48 per cent, while welfare for the rest of the region rises 22.8 per cent.

For the rest of SSA and the ROW, improvements in transportation infrastructure in Southern Africa have insignificant effects when private sector financed investment is supported by either subsidies or zeroroyalties concessions. Notwithstanding, for SSA, improvements in infrastructure in Southern Africa financed directly via government spending will increase GDP by 4 per cent, while changes in welfare as a percent of GDP will be 32 per cent.

To explain what is driving these results, I use the GDP identity and changes in private capital. The latter shows whether a particular policy crowds-in or crowds-out private investments. Changes in private investments and factor incomes in part explain how a policy can yield GDP losses and welfare gains at the same time.

The GDP identity described in Equation 6 shows that the expenditure-based measure of gross output (GDP) is made up of five components: private consumption $\left(C_{-} r\right)$; government expenditure $\left(G_{-} r\right)$; investment expenditure $\left(I \_r\right)$; and net exports-the difference between the value of exports $\left(E X P \_r\right)$; and imports $\left(I M P \_r\right)$. Positive gains in the first four components will increase GDP, while a rise in the last component (imports), will reduce GDP.

$$
G D P_{r}=C_{r}+G_{r}+I_{r}+\left(E X P_{r}-I M P_{r}\right)
$$

The main factors behind RSA's lower GDP are lower private domestic consumption and a rise in imports. For imports, first, an improvement in transport infrastructure lowers the cost of transporting goods and the effective price of imports, and as a result imports rise. More importantly, the results show that the real exchange rate appreciates under all policy scenarios, which causes imports to rise relative to exports. While investment and exports also rise, these two effects are not large enough to offset higher imports; as a consequence, GDP falls. While the real exchange rate appreciates for the RSNA, GDP is higher because gains in investment more than offset the rise in imports. Furthermore, unlike RSA, private consumption in RSNA rises under all three policy scenarios.

Welfare effects are sensitive to the way transport infrastructure investments are financed. For RSA, offering resource concessions for investments via subsidies or waiving royalties results in welfare gains in spite of lower GDP. This is because, in this model, welfare is measured by a combination of effects including utility and factor incomes.

Table 4 illustrates the changes in private capital across the four regions. For the policy- implementing regions, infrastructure improvements financed through resource sector concessions crowd-in private capital compared to direct financing via government revenue. For South Africa, the increase in private capital is almost the same under rebate concessions ( 4.5 per cent) and zero-royalty concessions (4.2 per cent). For the rest of Southern Africa, the crowding-in effect is particularly stronger when zero-royalty concessions are used. This result reflects findings in the literature that RFI schemes are less distortionary 
than financing through government tax revenue. ${ }^{3}$ This also explains in part South Africa's GDP losses and positive welfare gains under the concession-based simulations.

\begin{tabular}{rrrrr}
\multicolumn{6}{c}{ Table 4: Change in private capital (\%) } \\
\hline & RSA & RSNA & SSA & ROW \\
\hline Sim 1 & 4.54 & 12.00 & -0.10 & -0.99 \\
Sim 2 & 4.19 & 16.10 & -0.07 & -0.68 \\
Sim 3 & 0.89 & 0.14 & -0.39 & 0.08 \\
\hline
\end{tabular}

Source: author's construction based on simulation results.

\subsection{Spatial effects}

To illustrate the spatial implications of transport improvements and the relative strengths of the two methods of financing, I examine changes in sectoral output, exports, employment, and land rates. The results support the existing literature in that reducing market failures by providing transport infrastructure can spur the growth of other sectors. Notwithstanding, the implications are markedly different for South Africa and the rest of the Southern African region. For South Africa, the manufacturing sector gains the most, while improvements in transport infrastructure stimulate the agriculture sector in the rest of the Southern African region. I discuss these changes region by region.

\section{South Africa (RSA)}

Figure 2 illustrates changes in sectoral output in RSA. It shows that output in all of the sectors apart from manufacturing declines when infrastructure improvements are financed through resource sector concessions. In contrast, output in agriculture, mining, manufacturing, and transport expands under the revenue-financed scenario. But in all three cases, transport infrastructure improvements stimulate manufacturing activity. Correspondingly, RSA's trade balance in manufacturing improves relative to the baseline.

Figure 2: RSA: changes in sectoral output

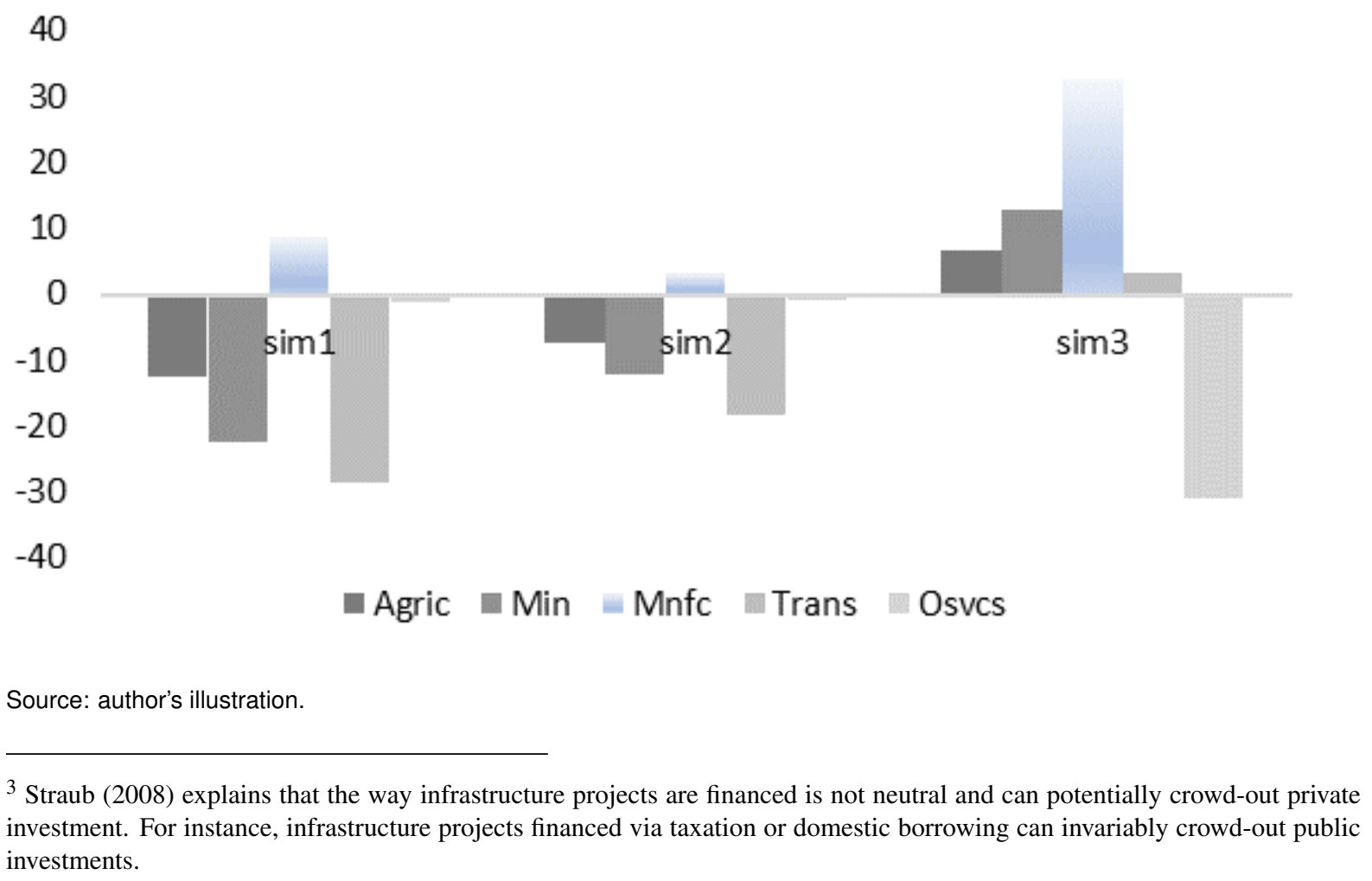


Table 5 shows that net exports are 9.4, 5, and 13.1 per cent under the three policy scenarios, respectively. This pattern suggests that part of the expansion in manufacturing is due to a rise in export demand relative to imports. As in the case of output, the improvement in manufacturing net exports is stronger under government-financed transport improvements. In contrast, agriculture and transport services exports are lower than the baseline.

\begin{tabular}{|c|c|c|c|c|c|c|c|c|c|}
\hline & \multicolumn{3}{|c|}{$\begin{array}{l}\text { Change in trade } \\
\text { balance (\% GDP) }\end{array}$} & \multicolumn{3}{|c|}{$\begin{array}{l}\text { Employment } \\
\text { effects (\%) }\end{array}$} & \multicolumn{3}{|c|}{$\begin{array}{l}\text { Land prices } \\
\text { change (\%) }\end{array}$} \\
\hline & $\operatorname{Sim} 1$ & $\operatorname{Sim} 2$ & $\operatorname{Sim} 3$ & $\operatorname{Sim} 1$ & $\operatorname{Sim} 2$ & $\operatorname{Sim} 3$ & Sim 1 & $\operatorname{Sim} 2$ & $\operatorname{Sim} 3$ \\
\hline Agric & -1.0 & -0.5 & -1.4 & -12.1 & -7.1 & 3.2 & -18.6 & -7.7 & 43.7 \\
\hline Mining & -0.8 & 0.0 & 1.1 & -23.1 & -11.6 & -4.6 & -34.1 & -12.3 & 24.1 \\
\hline Mnfc & 9.4 & 5.0 & 13.1 & -62.0 & -35.4 & -77.0 & -33.6 & -15.6 & -28.9 \\
\hline Trans & -8.2 & -5.0 & -5.9 & 98.2 & 57.1 & 29.7 & 77.6 & 48.6 & 52.5 \\
\hline Osvcs & 0.4 & 0.3 & -7.4 & -16.3 & -10.0 & 26.2 & 4.5 & 5.6 & 54.7 \\
\hline
\end{tabular}

Source: author's construction based on simulation results.

The fall in domestic agriculture production is due to a rise in imports of agricultural products from the rest of the Southern Africa region. Additionally, Table 5 also shows employment gains in agriculture (3.1 per cent) corresponding to higher output under the government-financed approach. Interestingly, employment in the manufacturing sector falls significantly under all three scenarios, possibly indicating that higher manufacturing demand is being met by increased capital intensity of production. These employment effects are consistent with findings by Ayogu (2007) that improvements in transport infrastructure can increase unemployment.

These results suggest that the effects of transport improvements on sectoral output, exports, employment, and land prices are sensitive to the method of infrastructure financing. Gains are highest when infrastructure improvements are made by government expenditure using royalty revenue.

\section{The rest of Southern Africa}

Figure 3 illustrates changes in sectoral output across the three policy scenarios. Comparing these output changes with those presented in Figure 3 reveals two key differences. First, for RSNA, sectoral output changes are negligible when infrastructure improvements are financed through resource concessions. Second, manufacturing output is lower than the baseline under the concession-based simulations. While negligible, the agriculture, mining, and service sectors experience higher output under the rebate scenario (Sim 1) compared to the zero-royalty scenario ( $\operatorname{Sim} 2$ ). The pattern of output changes under the government-financed scenario is similar to that for RSA; all sectors apart from services expand, and the expansion is particularly stronger in manufacturing.

Changes in RSNA sectoral exports, employment, and land rates are presented in Table 6. Here again, the pattern of changes under the concession-based simulations differs from that for South Africa. For instance, when infrastructure improvements are financed by offering mining firms rebates, net exports and employment expand in all sectors apart from manufacturing. Net exports and employment are 15 and 4.2 per cent higher relative to the baseline in agriculture, and 2.5 and 9 per cent in the service sector. In contrast, net manufacturing exports more than double under the government-financed scenario. The latter suggests that an improvement in the flow of goods expands the region's manufacturing sector. But, like RSA, employment in manufacturing falls significantly. The differences in employment changes in agriculture and manufacturing are due to differences in technology. In Southern Africa, manufacturing tends to be more capital-intensive than agriculture. 


\section{0}

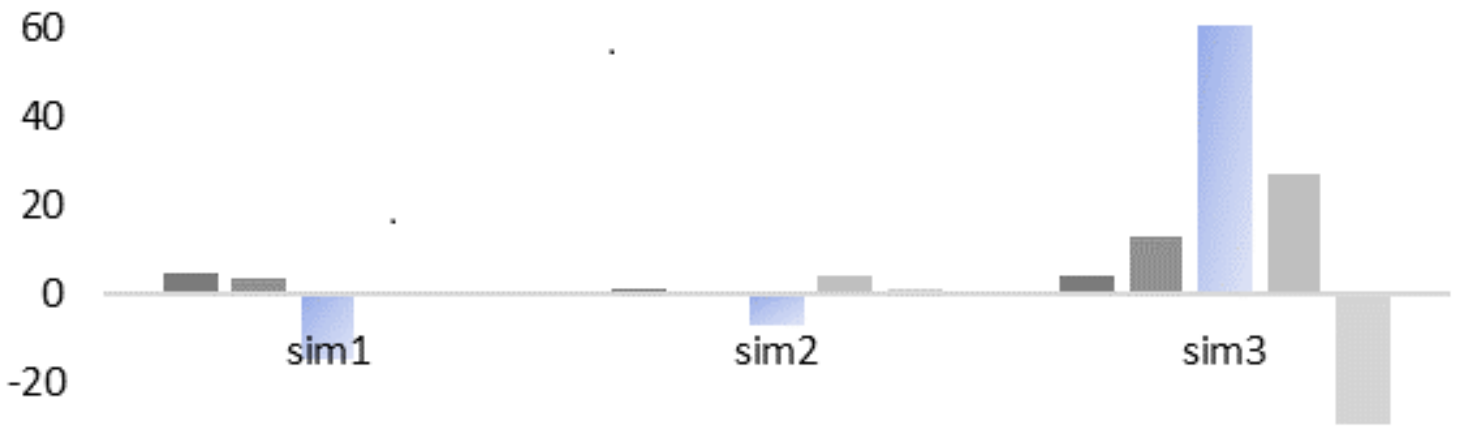

\section{agric $\quad$ Min $\square$ Mnfc $\square$ Trans $\square$ Osves}

Source: author's illustration.

Table 6: Rest of Southern Africa: spatial effects

\begin{tabular}{|c|c|c|c|c|c|c|c|c|c|}
\hline & \multicolumn{3}{|c|}{$\begin{array}{l}\text { Change in trade } \\
\text { balance (\% GDP) }\end{array}$} & \multicolumn{3}{|c|}{$\begin{array}{l}\text { Employment } \\
\text { effects (\%) }\end{array}$} & \multicolumn{3}{|c|}{$\begin{array}{l}\text { Land prices } \\
\text { change (\%) }\end{array}$} \\
\hline & Sim 1 & $\operatorname{Sim} 2$ & $\operatorname{Sim} 3$ & $\operatorname{Sim} 1$ & Sim 2 & $\operatorname{Sim} 3$ & $\operatorname{Sim} 1$ & Sim 2 & $\operatorname{Sim} 3$ \\
\hline Agric & 15.0 & 7.0 & -28.8 & 4.2 & 2.0 & 0.9 & 17.8 & 11.7 & 41.4 \\
\hline Mining & 17.4 & 10.0 & 3.6 & 6.3 & 2.3 & -2.4 & 19.1 & 10.8 & 33.3 \\
\hline Mnfc & -36.2 & -17.0 & 153 & 16.0 & 15.2 & -54.6 & 18.4 & 18.1 & -6.1 \\
\hline Trans & 2.5 & 4.1 & -3.2 & -32.6 & -27.6 & -41.1 & -14.8 & -11.3 & 13.3 \\
\hline Osvcs & 2.5 & -2.6 & .. & 9.0 & 11.5 & 61.9 & 12.3 & 14.6 & 87.1 \\
\hline
\end{tabular}

Source: author's construction based on simulation results.

Like South Africa, the spatial effects of transport infrastructure improvements in the rest of Southern Africa depend on the method of financing infrastructure investments. Stimulating an expansion of manufacturing requires the direct government financing of infrastructure improvements. However, this would result in a fall in employment in the sector. Finally, according to Table 6, concession-based infrastructure improvements are less distortionary.

\section{Implications for SSA and the rest of the world}

Improvements in infrastructure in the Southern African region have secondary effects on other regions. Figures A1 and A2 in the Appendix illustrate how these policies affect sectoral output in SSA and ROW. For the rest of SSA, the manufacturing sector is sensitive to improvements in transportation infrastructure in Southern Africa. Mining and manufacturing net exports are higher than the baseline under the concession-based simulations, while manufacturing exports are lower under the government-financed scenario. Higher manufacturing output and lower net exports suggest increased domestic demand for manufacturing goods. For ROW, the trade effects are negligible.

\section{$5 \quad$ Conclusion}

This paper explores how Southern Africa can leverage its mineral resources to support spatial development and industrialization. It uses a four-region CGE framework to simulate and compare the effects of financing transport infrastructure improvements via resource sector concessions and direct government expenditures. It incorporates mineral royalties as land-use taxes in the mining sectors. It considers 
two types of resource sector concessions: (1) subsidies/rebates to royalty-paying mining firms; and (2) outright waiving of mineral royalties in exchange for the provision of critical transport infrastructure. Among the four regions, RSA and RSNA apply infrastructure improvements using the three methods of financing.

The aggregate effects of the simulations vary across the two implementing regions. For South Africa, improvements in transport infrastructure reduce GDP regardless of the method of financing. But the GDP effects are particularly stronger when infrastructure improvements are financed via direct government expenditures using revenue from mineral royalties. While counter-intuitive, the fall in GDP arises because better transportation increases imports more than exports and investment. Furthermore, GDP losses are particularly higher under the government-financed policy because it is more distortionary. In contrast, RSNA experiences higher GDP under all three policy scenarios. Like RSA, GDP effects are much stronger when infrastructure improvements are financed through direct government expenditures. For both regions, concessions-for-infrastructure simulations yield overall welfare gains.

Spatial effects are modelled as employment, sectoral, capital, and land price effects. Results show that improvements in transport infrastructure can stimulate activity in sectors outside mining. This lends support to the literature that suggests that carefully targeted infrastructure investments can partially offset the Dutch Disease by stimulating activity in tradable sectors. For South Africa, manufacturing output and exports expand under all three policy scenarios. But unlike the literature supporting RFI initiatives, the largest manufacturing gains are seen when the government actively invests royalty revenue in transport infrastructure improvements. For RSNA, sectoral gains come mainly from agriculture. The differences in sectoral effects between RSA and the rest of the region perhaps reflect the pattern of comparative advantage of countries trading within the Southern African region.

Strauss-Khan (2010) asserts that 'there are a few areas of economic policy-making in which the returns to good decisions are so high — and the punishment of bad decisions so cruel—as in the management of natural resource wealth'. A key result of the preceding analysis suggests that, if used properly, revenue collected from mineral royalties can provide bottleneck-easing transport infrastructure and spur spatial activity. Second, improvements in transport infrastructure can stimulate spatial development in resource-dependent regions. Third, if the objective is to get strong sectoral changes, the method of financing matters. Stronger spatial effects are observed when the government actively invests in transport infrastructure improvements than when it offers concessions to mining firms in exchange for infrastructure. Notwithstanding, if the objective of a government is to stimulate spatial development in the least distortionary way, then the concessionary approach would be better. Furthermore, the literature suggests that RFI schemes have the benefit of speed. Also, they force the otherwise disinterested resource sector to actively participate in communities in which they operate and create a sense of giving back.

It is worth mentioning that the conclusions of this paper derive from a static framework, and as such should be interpreted with caution. Benefits of infrastructure investments take time to realize. A dynamic framework can offer richer insights, but because of time constraints, this analysis could only allow for a single-period analysis. Given that this is an important and practical policy issue, the dynamic treatment of the questions raised in this paper is left for future research. In addition to the one-period treatment, readers should also be mindful that results of this CGE analysis are driven by model assumptions and the choice of parameters. These concerns notwithstanding, the conclusions of this paper are consistent with both theoretical and empirical literature of infrastructure investments and spatial development. The results that suggests that financing infrastructure investments through resource sector concessions is less distortionary than through royalty revenue are especially important. 


\section{References}

AfDB (2019). Southern African Economic Outlook, 2019. Abidjan: African Development Bank Group.

Ayogu, M. (2007). 'Infrastructure and Economic Development in Africa: A Review'. Journal of African Economies, 16(suppl. 1): 75-126.

Boadway, R., and M. Keen (2010). 'Theoretical Perspectives on Resource Tax Design'. In P. Daniel, M. Keen, and C. McPherson (eds), The Taxation of Petroleum and Minerals: Principles, Problems and Practice. London: Routledge.

Bosker, M., and E. Buringh (2018). 'Ice(berg) Transport Costs'. CESifo Working Paper 6881. Munich: Leibniz Institute for Economic Research (ZBW).

Bunte, J.B., H. Desai, K. Gbala, B. Parks, and D.M. Runfola (2017). 'Government Policy and Natural Resource Sector FDI: Quasi-Experimental Evidence from Liberia'. World Development, 107: 151-62.

Chen, W., D. Dollar, and H. Tang (2018). 'Why Is China Investing in Africa? Evidence from the Firm Level'. World Bank Economic Review, 32(3): 610-32.

Collier, P. (2014). 'Comments'. In H. Halland, J. Beardsworth, B. Land, and J. Schmidt (eds), Resource Financed Infrastructure: A Discussion on a New Form of Infrastructure Financing. Washington, DC: World Bank.

Fernández, M., and V.M. Montuenga-Gómez (2003). 'The Effects of Public Capital on the Growth in Spanish Productivity'. Contemporary Economic Policy, 21(3): 383-93.

Halland, H., J. Beardsworth, B. Land, and J. Schmidt (2014). 'Resource Financed Infrastructure: A Discussion on a New Form of Infrastructure Financing'. Technical Report. Washington, DC: World Bank.

Limão, N., and A.J. Venables (2001). 'Infrastructure, Geographical Disadvantage, Transport Costs, and Trade'. World Bank Economic Review, 15(3): 451-79.

Lin, J.Y. and Y. Wang (2014). 'Comments'. In H. Halland, J. Beardsworth, B. Land, and J. Schmidt (eds), Resource Financed Infrastructure: A Discussion on a New Form of Infrastructure Financing. Washington, DC: World Bank.

Metcalfe, A., and D. Valeri (2019). 'Bridging the African Infrastructure Gap: Bringing Accountants to the Centre of the Decision-Making Process'. Technical Report. Toronto: Association of Chartered Certified Accountants.

Narayanan, B., A. Aguiar, and R. McDougall (eds) (2012). Global Trade, Assistance, and Production: The GTAP 8 Data Base. West Lafayette, IN: Center for Global Trade Analysis, Purdue University.

Parks, B. (2017). Getting Better Development Returns on Investment in the Natural Resource Sector'. Future Development, March.

Robson, E.N., K.P. Wijayaratna, and V. Dixit (2018). 'A Review of Computable General Equilibrium Models for Transport and Their Applications in Appraisal'. Transportation Research Part A: Policy and Practice, 116: 31-53.

Rovolis, A., and N. Spence (2002). 'Promoting Regional Economic Growth in Greece by Investing in Public Infrastructure'. Environment and Planning C: Politics and Space, 20(3): 393-419.

Sachs, J.D., and A.A. Warner (1995) 'Natural Resource Abundance and Economic Growth'. Working Paper 5398. Cambridge, MA: NBER. 
Sachs, J.D., and A.A. Warner (1997). 'Sources of Slow Growth in African Economies'. Journal of African Economies, 6(3): 335-76.

Saghir, J. (2017) 'Sustainable Infrastructure Development in Sub Saharan Africa: A View from the Ground'. Research to Practice Policy Brief PB-2017-02. Montreal: Institute for the Study of International Development (ISID), McGill University.

Straub, S. (2008). 'Infrastructure and Growth in Developing Countries: Recent Advances and Research Challenges'. Policy Research Working Paper 4460. Washington, DC: World Bank.

Straub, S., and A. Terada-Hagiwara (2011). 'Infrastructure and Growth in Developing Asia'. Asian Development Review, 28(1): 119-56.

Strauss-Khan, D. (2010). 'Preface'. In P. Daniel, M. Keen, and C. McPherson (eds), The Taxation of Petroleum and Minerals: Principles, Problems and Practice. New York: Routledge.

Toledano, P. (2012). 'Leveraging Extractive Industry Infrastructure Investments for Broad Economic Development: Regulatory, Commercial and Operational Models for Railways and Ports'. CCSI Policy Paper. New York: Columbia Center on Sustainable Development.

UNCTAD (2019). 'World Investment Report, 2019: Special Economic Zones'. Technical Report. Geneva: UNCTAD.

Venables, A.J. (2016). 'Using Natural Resources for Development: Why Has It Proven so Difficult?'. Journal of Economic Perspectives, 30(1): 161-84. 
Appendix: extra results

Figure A1: SSA: sectoral output changes

15

10

$-5$ $\operatorname{sim} 1$

$-10$

$\square$ Agric $\square$ Min $\square$ Mnfc $\square$ Trans $\square$ Osves

Source: author's illustration.

Figure A2: ROW: sectoral output changes

8.0

6.0

4.0

2.0

0.0

$-2.0$

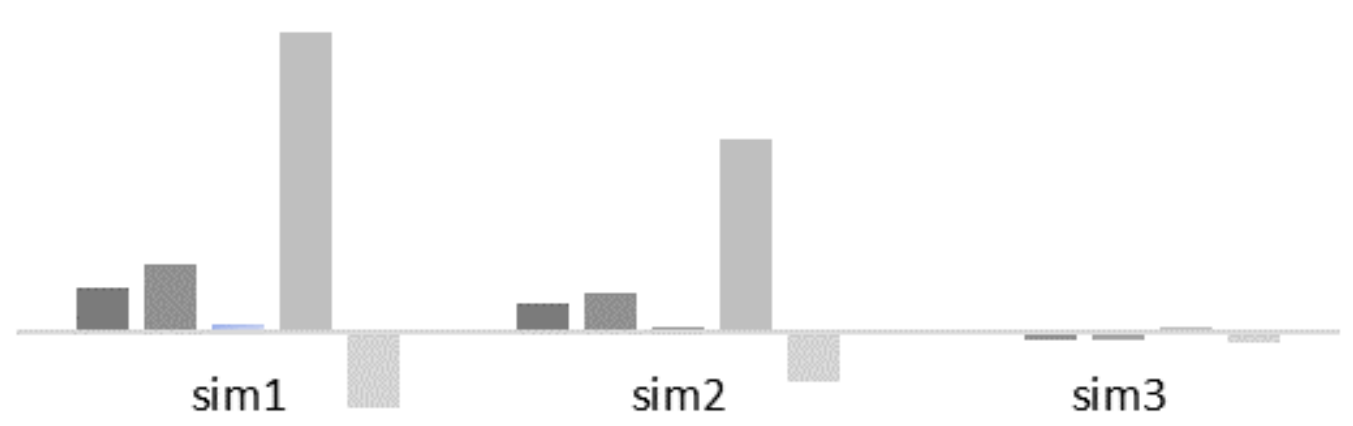

Agric Min Mnfc $\square$ Trans ${ }^{-}$Osvcs

Source: author's illustration. 
Table A1: Rest of sub-Saharan Africa: spatial effects

\begin{tabular}{|c|c|c|c|c|c|c|c|c|c|}
\hline & \multicolumn{3}{|c|}{$\begin{array}{l}\text { Change in trade } \\
\text { balance (\%GDP) }\end{array}$} & \multicolumn{3}{|c|}{$\begin{array}{l}\text { Employment } \\
\text { effects (\%) }\end{array}$} & \multicolumn{3}{|c|}{$\begin{array}{l}\text { Land prices } \\
\text { change (\%) }\end{array}$} \\
\hline & $\operatorname{Sim} 1$ & $\operatorname{Sim} 2$ & $\operatorname{Sim} 3$ & $\operatorname{Sim} 1$ & Sim 2 & $\operatorname{Sim} 3$ & $\operatorname{Sim} 1$ & $\operatorname{Sim} 2$ & $\operatorname{Sim} 3$ \\
\hline Agric & -3.2 & -2.4 & 2.9 & -0.87 & -0.72 & 7.86 & 0.07 & 0.22 & 25.26 \\
\hline Mining & 2.2 & 2.1 & 1.6 & -1.07 & -0.9 & 1.35 & 0.25 & 0.36 & 5.02 \\
\hline Mnfc & 11.7 & 8.3 & -5.7 & -6.11 & -4.87 & 4.4 & -2.37 & -1.63 & 5.63 \\
\hline Trans & -11.2 & -8.0 & 1.2 & 6.08 & 5.67 & -3.75 & 6.38 & 5.85 & -0.28 \\
\hline Osvcs & 1.0 & 0.4 & 0.8 & 0.25 & -0.25 & -4.94 & 2.83 & 2.17 & -1.84 \\
\hline
\end{tabular}

Source: author's construction based on simulation results.

Table A2: Rest of the world: spatial effects

\begin{tabular}{|c|c|c|c|c|c|c|c|c|c|}
\hline & \multicolumn{3}{|c|}{$\begin{array}{l}\text { Change in trade } \\
\text { balance (\%GDP) }\end{array}$} & \multicolumn{3}{|c|}{$\begin{array}{l}\text { Employment } \\
\text { effects (\%) }\end{array}$} & \multicolumn{3}{|c|}{$\begin{array}{l}\text { Land prices } \\
\text { change (\%) }\end{array}$} \\
\hline & $\operatorname{Sim} 1$ & $\operatorname{Sim} 2$ & $\operatorname{Sim} 3$ & Sim 1 & $\operatorname{Sim} 2$ & $\operatorname{Sim} 3$ & Sim 1 & $\operatorname{Sim} 2$ & $\operatorname{Sim} 3$ \\
\hline Agric & 0.2 & 0.1 & 0.1 & 1.25 & 0.81 & 0.02 & 2.73 & 2.1 & -0.2 \\
\hline Min & 0.3 & 0.1 & -0.1 & 2.41 & 1.57 & -0.23 & 4.04 & 3.17 & -1.08 \\
\hline Mnfc & 0.3 & 0.2 & -0.9 & 4.43 & 2.87 & -0.46 & 2.65 & 2.05 & -0.64 \\
\hline Trans & -0.7 & -0.4 & 0.3 & -25.31 & -16.38 & -0.51 & -16.55 & -10.38 & -0.58 \\
\hline Osves & 0.0 & 0.0 & 0.6 & 7.46 & 4.83 & 0.42 & 4.86 & 3.47 & 0.06 \\
\hline
\end{tabular}

Source: author's construction based on simulation results. 